\title{
A new species of Zachaeus C.L. Koch from Turkey (Opiliones, Phalangiidae)
}

\author{
Kemal Kurt', Halil Koç², Ersen Aydın Yağmur ${ }^{3}$ \\ I Gümüşane University, Şiran Vocational High School, TR-29700 Gümüşhane, Turkey 2 Sinop University, \\ Science and Art Faculty, Biology Department, Sinop, Turkey 3 Alasehir Vocational School, Celal Bayar University, \\ TR-45600, Alaşehir, Manisa, Turkey
}

Corresponding author: Kemal Kurt (kemalkurtmyo@gmail.com)

Academic editor: A. Kury | Received 6 March 2015 | Accepted 29 June 2015 | Published 22 July 2015

http://zoobank.org/E273CFOD-A882-49B3-8AA9-D85A489B753E

Citation: Kurt K, Koç H, Yağmur EA (2015) A new species of Zachaeus C.L. Koch from Turkey (Opiliones, Phalangiidae). ZooKeys 514: 15-23. doi: 10.3897/zookeys.514.9545

\begin{abstract}
A new species of harvestmen, Zachaeus seyyari sp. n. (Opiliones, Phalangiidae), is described and illustrated on the basis of both sexes from Şırnak Province in Turkey. Differences between the new species and related species are indicated. Photographs of its characteristic structures are also provided.
\end{abstract}

\section{Keywords}

Opiliones, Phalangiidae, Zachaeus, new species, Turkey

\section{Introduction}

Zachaeus C.L. Koch, 1839 is a genus belonging to the subfamily Phalangiinae of the Phalangiidae and it is distributed in the eastern part of the Mediterranean Region, south-eastern Europe, and western Asia (Snegovaya and Staręga 2008). The genus includes 12 species: $Z$. anatolicus (Kulczynski, 1903), Z. birulai (Redikorzev, 1936), $Z$. crista (Brullé, 1832), Z. hebraicus (Simon, 1884), Z. hyrcanus (Redikorzev, 1936), Z. kervillei (Sørensen, 1912) species inquirenda, Z. lupatus (Eichwald, 1830), Z. mirabilis (Caporiacco, 1949), Z. orchimonti (Giltay, 1933), Z. redikorzevi (Staręga \& Chevrizov, 1978), Z. shachdag (Snegovaya \& Staręga, 2008), and Z. simferopolensis (Chemeris \&

Copyright Kemal Kurt et al. This is an open access article distributed under the terms of the Creative Commons Attribution License (CC BY 4.0), which permits unrestricted use, distribution, and reproduction in any medium, provided the original author and source are credited. 
Kovblyuk, 2005) [Giltay 1933; Redikorzev 1936; Caporiacco 1949; Snegovaya and Staręga 2008], of which five are known in Turkey: $Z$. anatolicus, $Z$. crista, $Z$. hebraicus, $Z$. orchimonti, and $Z$. redikorzevi (Kurt, 2014).

The genus is characterized by the following morphological characteristics: body large, heavily denticulated dorsally; chelicerae usually strong, second segment enlarged; pedipalps normally structured, strong, robust; legs short and first pair much thicker than the others; truncus penis basally widened, parallel-sided on the distal half, distally shallow spoon-shaped, glans usually banana-shaped (shorter in $Z$. anatolicus and $Z$. seyyari), stylus long (Snegovaya and Staręga 2008, 2009). Here, we describe a new species of the genus Zachaeus from Şırnak Province in Turkey, and compare it to the most similar species.

\section{Material and methods}

Samples were collected by hand from the meadows and grassland in Şırnak Province, Turkey. Species identification was conducted using a Leica EZ4 stereomicroscope. Specimens are preserved in 70\% ethanol and deposited in the collection of the Arachnological Laboratory of Şiran Vocational School, Gümüşhane University (GUSAL), Turkey. All measurements are given in millimeters.

\section{Results}

\section{Taxonomy}

Family Phalangiidae Latreille, 1802

Genus Zachaeus C.L. Koch, 1839

\section{Zachaeus seyyari sp. $\mathrm{n}$.}

http://zoobank.org/89BE1BA3-8AEE-4CB1-A1F2-17B789F8BB6C

Figs $1-4$

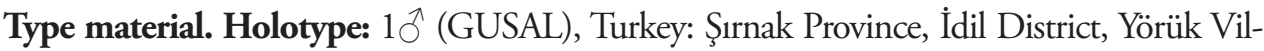
lage (37 16'47.54"N, 42 1'17.18"E), 655 m, 12 May 2007, leg. E.A. Yağmur and H. Koç.

Paratypes. 20,4 (GUSAL), 1 ô, 19 (AZMM=Alaşehir Zoological Museum, Manisa) same data as holotype.

Distribution. Up to now only known from type locality in the Şırnak Province, Turkey.

Diagnosis. The new species is similar to $Z$. anatolicus (Kulczyński 1903: 660; Šilhavý 1956: 34, figs 1-5; -1965: 382-384, figs 1-13, Staręga 1976: 376, figs 75-77; Chevrizov 1979: 22, figs 119-121) and Z. redikorzevi (Staręga and Chevrizov 1978: 419-422, figs 1-2; Staręga 1978: 219; Chevrizov 1979: 22, figs 122-124; Kurt et al. 2011: 146-147, figs 1-8). The differences between these species are given in Table 1. 

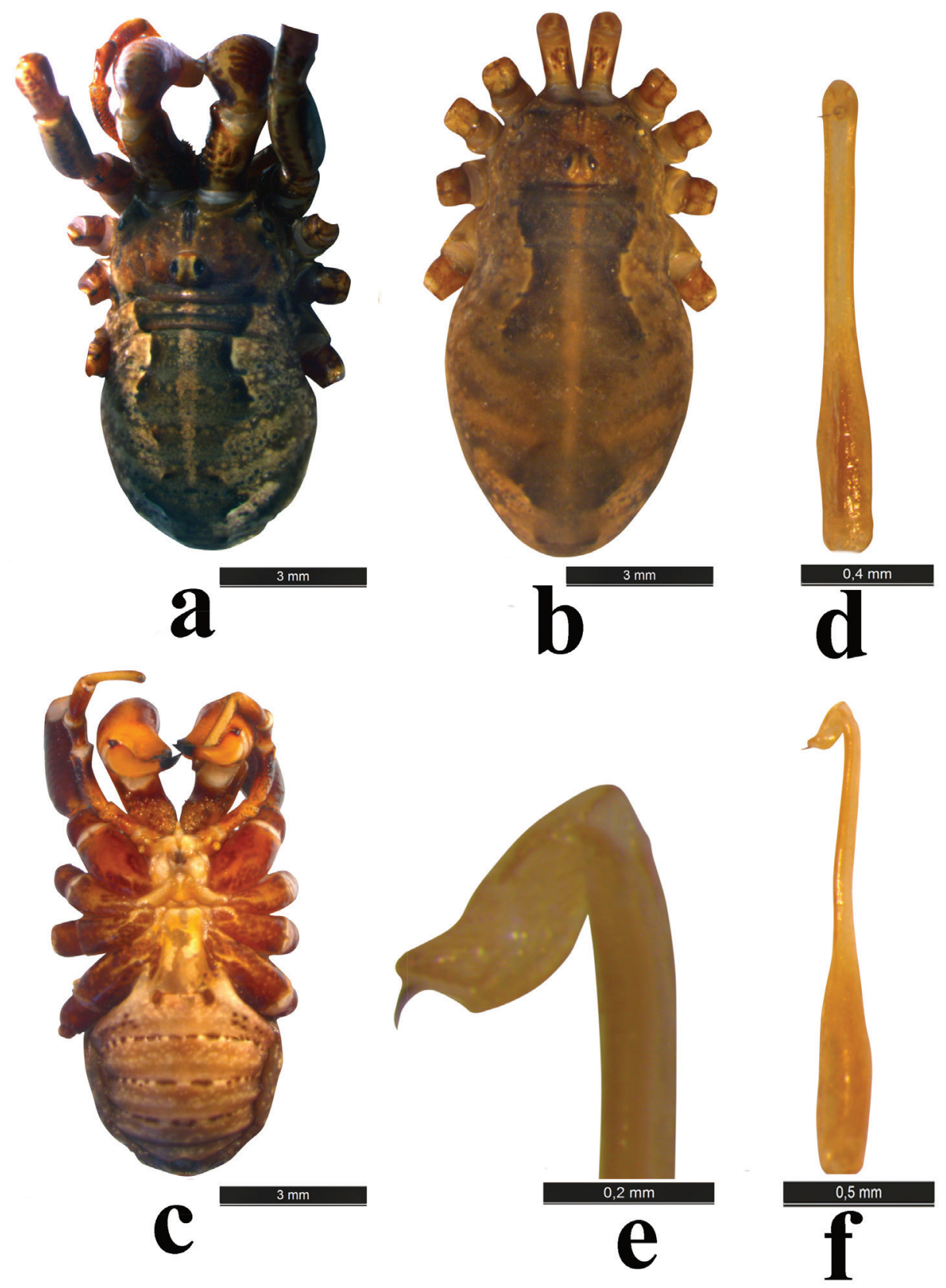

Figure I. Z. seyyari sp. n.: a body, male, dorsal view b body, female, dorsal view c body, male, ventral view $\mathbf{d}$ penis, dorsal view e glans, lateral view $\mathbf{f}$ penis, lateral view.

Derivatio nominis. The specific epithet is in honor of Dr. Osman SEYYAR (Niğde University, Niğde, Turkey), who has made important contributions to Turkish arachnology. 
Table I. Main diagnostic characters of most closely related species in the genus Zachaeus.

\begin{tabular}{|c|c|c|c|}
\hline Characters & Z. seyyari sp. $\mathrm{n}$. & Z. anatolicus & Z. redikorzevi \\
\hline Body & $\begin{array}{l}\text { cephalothorax dorsally with small } \\
\text { denticles; abdomen dorsally not } \\
\text { denticulated }\end{array}$ & $\begin{array}{c}\text { cephalothorax and } \\
\text { abdomen dorsally with } \\
\text { numerous denticles } \\
\text { (Staręga 1976). }\end{array}$ & $\begin{array}{c}\text { cephalothorax dorsally only } \\
\text { granulated on surface, abdomen } \\
\text { dorsally not denticulated } \\
\text { (Staręga and Chevrizov 1978) }\end{array}$ \\
\hline $\begin{array}{c}\text { Tuber } \\
\text { oculorum }\end{array}$ & $\begin{array}{l}\text { relatively low and } 1-2 \text { setae in } \\
\text { two rows }\end{array}$ & $\begin{array}{l}\text { low and 4-8 tubercles in } \\
\text { two rows (Staręga 1976). }\end{array}$ & $\begin{array}{c}\text { low and 5-6 tubercles in two rows } \\
\text { (Starega and Chevrizov 1978) }\end{array}$ \\
\hline $\begin{array}{l}\text { Chelicerae } \\
\text { of male }\end{array}$ & $\begin{array}{l}\text { second segment swollen (more } \\
\text { cylindrical), covered with setae. }\end{array}$ & $\begin{array}{c}\text { second segment not } \\
\text { swollen, covered with } \\
\text { setae and microdenticles } \\
\text { (Staręga 1976). }\end{array}$ & $\begin{array}{c}\text { second segment extraordinarily } \\
\text { swollen, covered with setae and } \\
\text { microdenticles (Staręga and } \\
\text { Chevrizov 1978) }\end{array}$ \\
\hline $\begin{array}{l}\text { Palp of } \\
\text { male }\end{array}$ & $\begin{array}{l}\text { patella dorsally with setae; tibia } \\
\text { with setae. }\end{array}$ & $\begin{array}{c}\text { patella dorsally with } \\
\text { microdenticles, tibia with } \\
\text { setae and microdenticles } \\
\text { (Staręga 1976). }\end{array}$ & $\begin{array}{c}\text { patella dorsally with setae; tibia } \\
\text { only with setae (Staręga and } \\
\text { Chevrizov 1978) }\end{array}$ \\
\hline Leg & $\begin{array}{l}\text { femur I-III with setae; femur } \\
\text { IV ventrally with denticles, } \\
\text { dorsally setae. }\end{array}$ & $\begin{array}{c}\text { femur I-IV with denticles } \\
\text { (Staręga 1976). }\end{array}$ & $\begin{array}{c}\text { femur I-III with setae; femur IV } \\
\text { ventrally with denticles (Starega } \\
\text { and Chevrizov 1978) }\end{array}$ \\
\hline Penis & $\begin{array}{l}\text { truncus wide at the base, basal to } \\
\text { center with straight sides; then } \\
\text { slightly narrowed at the center; then } \\
\text { not widened, straight-sided at the } \\
\text { subapex; glans stocky, not elongated, } \\
\text { parallel sided, ventrally slightly oval- } \\
\text { sided, apical outline rectangular. }\end{array}$ & $\begin{array}{l}\text { truncus wide at the base, } \\
\text { base to center narrowed; } \\
\text { then widened at the } \\
\text { subapex; glans, stocky, not } \\
\text { elongated, ventrally oval } \\
\text { (Starega 1976). }\end{array}$ & $\begin{array}{l}\text { truncus slightly enlarged at the } \\
\text { proximal half; then straight-sided } \\
\text { in distal half; glans elongated } \\
\text { and narrow, ventrally oval-sided, } \\
\text { apical outline triangular (Staręga } \\
\text { and Chevrizov 1978) }\end{array}$ \\
\hline
\end{tabular}

Table 2. Measurements (in $\mathrm{mm}$ ) of male holotype (female paratype).

\begin{tabular}{c|c|c|c|c|c|c}
\hline & Femur & Patella & Tibia & Metatarsus & Tarsus & Total \\
\hline Palp & $1.7(1.5)$ & $0.9(0.85)$ & $1.2(0.95)$ & $-(-)$ & $1.9(1.7)$ & $5.7(5.0)$ \\
\hline Leg I & $3.2(2.8)$ & $1.4(1.2)$ & $2.94(2.2)$ & $2.7(2.1)$ & $4.2(4.0)$ & $14.44(12.3)$ \\
\hline Leg II & $3.8(3.4)$ & $1.5(1.4)$ & $3.5(3.1)$ & $3.7(3.1)$ & $7.9(7.8)$ & $20.4(18.8)$ \\
\hline Leg III & $2.3(2.1)$ & $1.3(1.1)$ & $2.5(2.1)$ & $3.0(2.9)$ & $4.8(4.7)$ & $13.9(12.9)$ \\
\hline Leg IV & $3.5(3.5)$ & $1.4(1.3)$ & $3.3(3.2)$ & $3.5(3.5)$ & $7.2(7.0)$ & $18.9(18.5)$ \\
\hline
\end{tabular}

Description. Male: body length $7.2 \mathrm{~mm}$, width $4.5 \mathrm{~mm}$; chelicera basal segment $2.8 \mathrm{~mm}$, second segment $3.7 \mathrm{~mm}$.

Body (Fig. 1a): approximately oval-shaped in dorsal view. Opening of odoriferous gland prominent with 1-2 black denticles. Cephalothorax covered with small black denticles. Carapace ochre-brown. Abdomen dorsally with distinct brownish-gray saddle. Saddle with longitudinal whitish-yellow stripe in the center. Abdominal tergites with transverse rows of dark brown spots, not denticulated.

Tuber oculorum (Fig. 4f): nearly hemispherical, median furrow present, relatively low and with 1-2 setae on each side. 


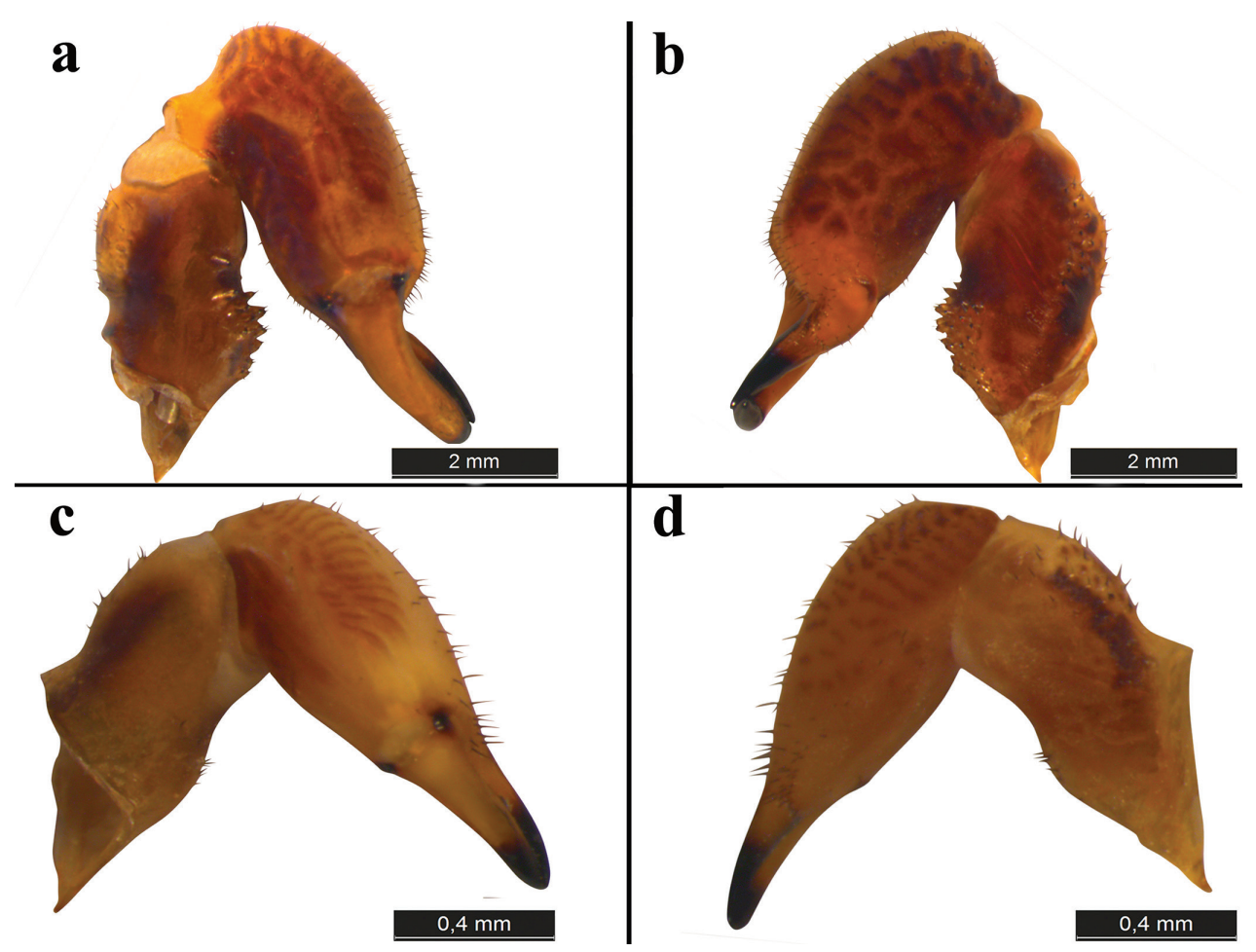

Figure 2. Chelicerae of $Z$. seyyari sp. n.: a, b chelicerae, male, lateral view c, $\mathbf{d}$ chelicera, female, lateral view.

Ventral side (Fig. 1c): coxae and genital operculum covered with sparse hairs. Abdomen ventrally with transverse rows of brown spots, and with sparse hairs.

Chelicerae (Fig. 2, 4e): strong, robust and dark ochre brown. Basal segment apically not widened and slightly bent, dorsally with small black-tipped tubercles and setae, ventrally with long black-tipped tubercles. Second segment apically widened, zebra-like stripe pattern of pigmentation, and covered with setae.

Pedipalp (Fig. 3): normally structured, strong; ochre-brown and with dark brown spots. Coxae with finger-shaped apophysis and covered with long setae; trochanter relatively long, ventrally and dorsally with black tubercles and setae; femur of male slighty curved, dorsally and ventrally covered with black-tipped tubercles and setae; patella distally with usual bulge densely hairy in female, less developed in male: similar in tibia; tibia and tarsus only with setae, but male tarsus ventrally bearing black microdenticles, tarsal claw smooth.

Legs (Fig. 4a-d): short and strong, light ochre-brown and with dark brown spots. Femur to tarsus I relatively thicker than in legs II to IV. Femur and patella I with setae, tibia ventrally with microdenticles and dorsally with setae, metatarsus ventrally covered with densely spaced microdenticles, tarsus bearing only setae. Leg pairs II and III with sparse setae. Femur and tibia IV ventrally covered with black denticles, and dorsally setae; metatarsus IV ventrally with bristle, dorsally with microdenticles; tarsus ventrally bristle, dorsally with setae. 


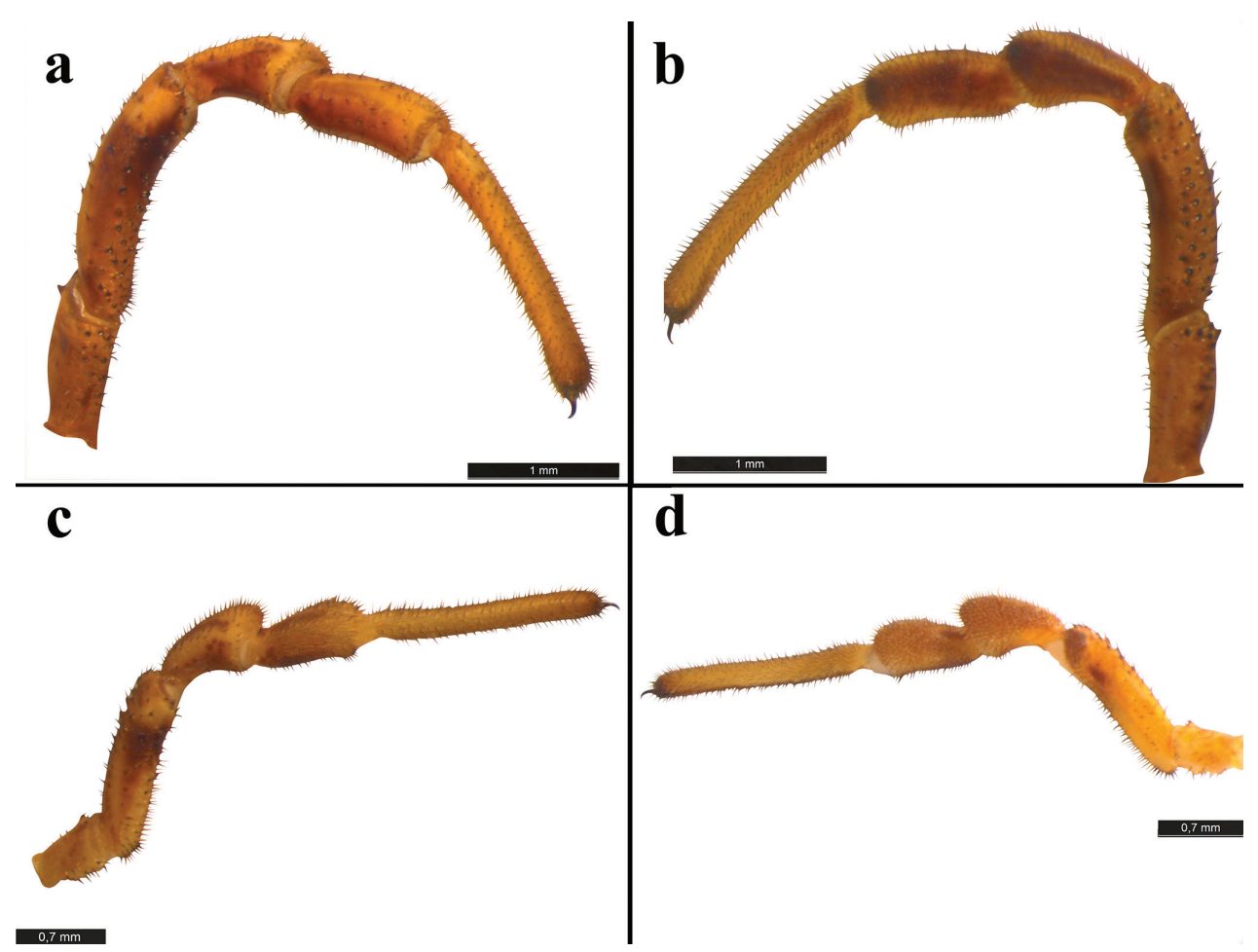

Figure 3. Pedipalp of $Z$. seyyari sp. n.: a, b pedipalp, male, lateral view $\mathbf{c}$, $\mathbf{d}$ pedipalp, female, lateral view.

Male genital morphology (Fig. 1d-f): truncus wide at base, proximal fourth of shaft straight-sided ; then slightly narrowed at the center; straight-sided from center to distal end of shaft, forming a spoon-shape, wings not very wide; glans stocky, widened, not elongated, not banana-shaped; stylus long.

Female: body length $9.0 \mathrm{~mm}$, width $4.7 \mathrm{~mm}$; chelicera basal segment $1.5 \mathrm{~mm}$, second segment $2.1 \mathrm{~mm}$. General appearance similar to that of male, but body larger and wider (Fig. 1b). Second segment of chelicerae normally structured, not enlarged, basal segment ventrally without tubercles.

Discussion. This paper describes a new species belonging to the genus Zachaeus. This genus has five species ( $Z$. anatolicus, $Z$. crista, $Z$. hebraicus, $Z$. orchimonti, and $Z$. redikorzevi) in Turkey. $Z$. anatolicus is distributed in Bulgaria, Caucasus, Crimea, Greece, former Yugoslavia, and Turkey (Adana, Ankara, Bayburt, Gümüşhane, Kayseri and Manisa Provinces) and $Z$. redikorzevi is recorded from Russia and Turkey (Bayburt, Gümüşhane, and Osmaniye Provinces) (Kurt 2014). Z. crista is distributed throughout South and Eastern Europe, Caucasus. It is widespread in Turkey (Ankara, Antalya, Bayburt, Bilecik, Bolu, Denizli, Gümüşhane, İzmir, Kırıkkale, Niğde and Osmaniye Provinces). Z. hebraicus is known from Jordan, Israel, Lebanon, Libya, Syria and Turkey (Adana, Manisa Provinces). Z. orchimonti is only known from Turkey (Aydın, Denizli, İzmir and Manisa Provinces) (Giltay, 1932) and Z. kervillei is known 


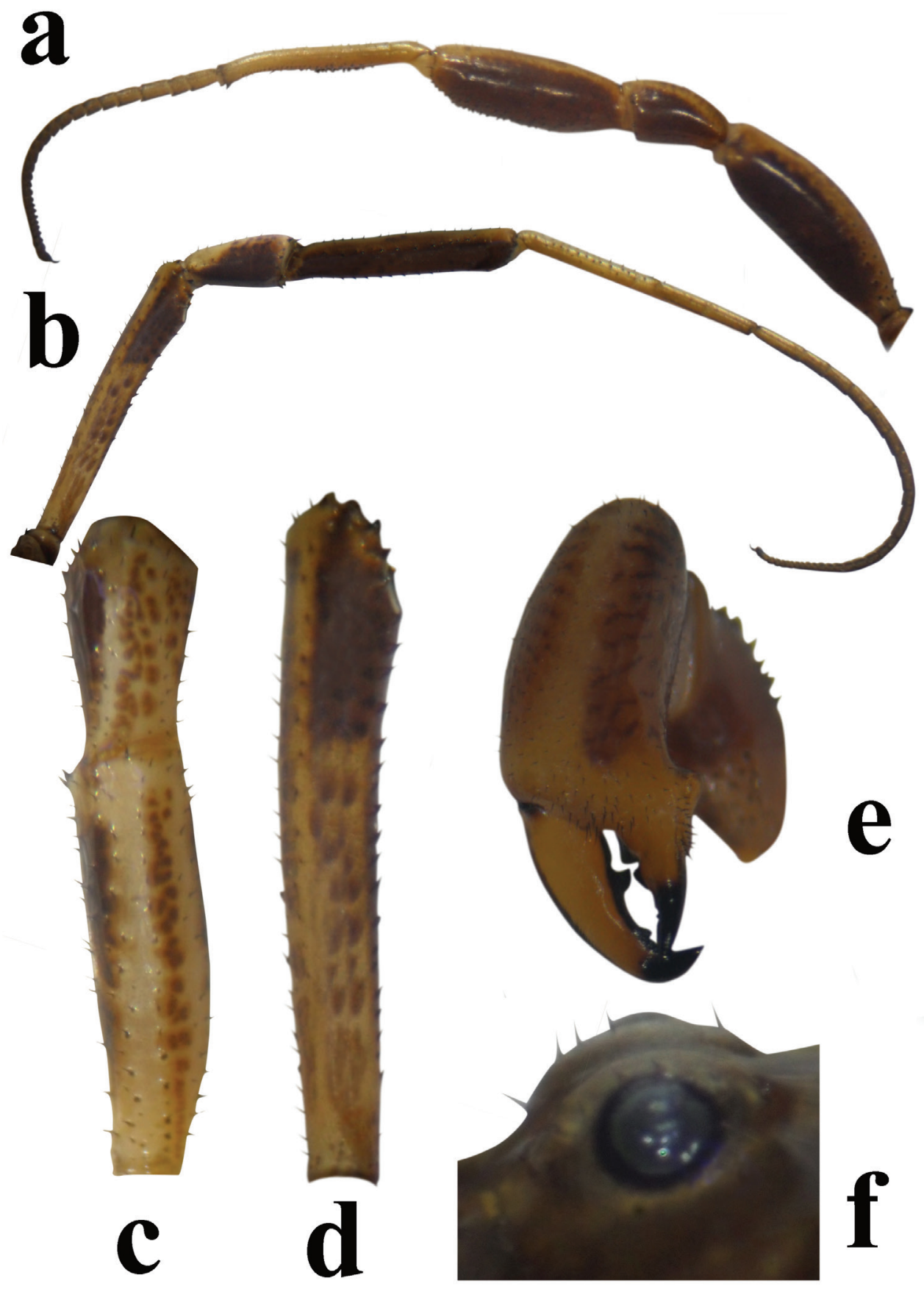

Figure 4. a, b Leg of $Z$. seyyari sp. n.: a pair I, male, lateral view b pair IV, male, lateral view $\mathbf{c}$ pair I femur and patella, female, dorsal view $\mathbf{d}$ pair IV femur, lateral view $\mathbf{e}$ chelicerae, male, frontal view $\mathbf{f}$ tuber oculorum, male, lateral view. 
from Syria (Roewer 1923). The new species differs from Z. hebraicus, Z. crista, and $Z$. kerville $i$ by the presence of setae only on the ocularium, abdomen not denticulated dorsally, and legs I-III femora covered with setae only (Z. hebraicus, $Z$. crista, and $Z$. kervillei are characterized by ocularium with denticles, abdomen dorsally denticulated, and leg I-III femora covered with denticles). Zachaeus seyyari sp. nov. differs from $Z$. orchimonti by a setose ocularium, femur of pedipalp dorsally and ventrally covered with black-tipped tubercles and setae (in Z. orchimonti, ocularium with 5-7 small denticles and femur of pedipalp with setae).

With Zachaeus seyyari sp. n., the number of Zachaeus species known from Turkey is now increased to 6 . Considering the geographical features of Turkeyand the habitat preferences of the genus, the number of species will surely increase with ongoing studies in the future.

\section{Acknowledgments}

We are grateful to Dr. A. Kury (Museu Nacional, Universidade Federal do Rio de Janeiro Rio de Janeiro, Brazil) and Dr. N. Snegovaya (Institute of Zoology, NAS of Azerbaijan) for advice and helpful comments.

\section{References}

Chevrizov BP (1979) A brief key to the harvestmen (Opiliones) from the European part of the USSR. The fauna and ecology of Arachnida. Proceedings of the Zoological Institute 85: 4-27. [In Russian]

Caporiacco L di (1949) Tre Aracnidi nuovi delle Madonie. Atti del museo civico di Storia naturale di Trieste 17: 126-131.

Giltay L (1932) Aracnides recueillis par M. D’Orchymont au cours de ses voyages aux Balkans et en Asie Mineure en 1929, 1930 et 1931. Bulletin du Musée Royal d'Histoire Naturelle de Belgique 8(22): 1-40.

Kulczyński W (1903) Arachnoidea in Asia Minore et ad Constantinopolima Dre. F. Werner collecta. Sitzungsberichte der K. Akademie der Wissenschaften, Mathematisch-naturwissenschaftliche Klasse (Vienna) 112: 627-680.

Kurt K, Snegovaya N, Demir H, Seyyar O (2011) New Data on the Harvestmen (Arachnida, Opiliones) of Turkey. Acta Zoologica Bulgarica 63(2): 145-150.

Kurt K (2014) Updated checklist of harvestmen (Arachnida: Opiliones) in Turkey. Archives of Biological Sciences, Belgrade 66(4): 1617-1631. doi: 10.2298/ABS1404617K

Redikorzev VV (1936) Materialy $k$ faune Opiliones SSSR. Proceedings of the Zoological Institute Akademija Nauk SSSR 3: 33-57.

Roewer CF (1923) Die Weberknechte der Erde. Systematische Bearbeitung der bisher bekannten Opiliones. Gustav Fischer, Jena, Deutchland, 1116 pp. 
Šilhavý V (1956) Výsledky zoologické expedice Národního musea v Praze do Turecka. Sborník Entomologického Oddělení Národního Musea v Praze 30: 31-39.

Šilhavý V (1965) Die Weberknechte der Unterordnung Eupnoi aus Bulgarien; zugleich eine Revision europaischer Gattungen der Unterfamilien Oligolophinae und Phalangiinae (Arachnoidea, Opilionidea). Acta entomologica bohemoslov 62: 369-406.

Snegovaya NY, Staręga W (2008) A new species of Zachaeus C.L. Koch from Azerbaijan (Opiliones, Phalangiidae). Acta Arachnologica 57(2): 71-73. doi: 10.2476/asjaa.57.71

Snegovaya NY, Staręga W (2009) Taurolaena, a new genus of Phalangiidae (Opiliones). Revista Ibérica de Aracnologia, Zaragoza 17: 37-44.

Staręga W (1976) Die Weberknechte (Opiliones, excl. Sironidae) Bulgariens. Annales Zoologici, Warsawa 33: 287-433.

Staręga W (1978) Katalog der Weberknechte (Opiliones) der Sowjet-Union. Fragmenta Faunistica 23(10): 197-241.

Staręga W, Chevrizov BP (1978) New species of the genus Zacheus C.L.Koch (Opiliones, Phalangiidae) from Northern Caucasus. Entomological Review 57(2): 419-422. 